\title{
Short communication: Regulation of hepatic gluconeogenic enzymes by dietary glycerol in transition dairy cows
}

\author{
H. M. White, ${ }^{* 1}$ E. R. Carvalho, ${ }^{* 2}$ S. L. Koser, ${ }^{*}$ N. S. Schmelz-Roberts, ${ }^{*}$ L. M. Pezzanite, ${ }^{*}$ A. C. Slabaugh, ${ }^{*}$ \\ P. H. Doane, $†$ and S. S. Donkin*3 \\ *Department of Animal Sciences, Purdue University, West Lafayette, IN 47907 \\ †Archer Daniels Midland Company, Decatur, IL 62521
}

\begin{abstract}
Nutritional status and glucose precursors are known regulators of gluconeogenic gene expression. Glycerol can replace corn in diets fed to dairy cows and use of glycerol is linked to increased rumen propionate production. The effect of dietary glycerol on the regulation of gluconeogenic enzymes is unknown. The objective of this study was to examine the effect of glycerol on expression of pyruvate carboxylase (PC), cytosolic and mitochondrial phosphoenolpyruvate carboxykinase (PEPCK-C and PEPCK-M), and glucose-6-phosphatase. Twenty-six multiparous Holstein cows were fed either a control diet or a diet where high-moisture corn was replaced by glycerol from -28 through $+56 \mathrm{~d}$ relative to calving (DRTC). Liver tissue was collected via percutaneous liver biopsy at $-28,-14,+1,+14,+28$, and +56 DRTC for RNA analysis. Expression of PC mRNA increased 6 -fold at +1 and 4 -fold at +14 DRTC relative to precalving levels. Dietary glycerol did not alter expression of PC mRNA expression. Expression of PEPCK-C increased 2.5-fold at +14 and 3-fold at +28 DRTC compared with +1 DRTC. Overall, dietary glycerol increased PEPCK-C expression compared with that of cows fed control diets. The ratio of $\mathrm{PC}$ to PEPCK-C was increased 6.3-fold at +1 DRTC compared with precalving and tended to be decreased in cows fed glycerol. We detected no effect of diet or DRTC on PEPCK-M or glucose-6-phosphatase mRNA, and there were no interactions of dietary treatment and DRTC for any transcript measured. Substituting corn with glycerol increased the expression of PEPCKC mRNA during transition to lactation and suggests that dietary energy source alters hepatic expression. The observed increase in PEPCK-C expression with
\end{abstract}

Received June 12, 2015.

Accepted August 21, 2015.

${ }^{1}$ Current address: Department of Dairy Science, University of Wisconsin, Madison 53706.

${ }^{2}$ Current address: Goiano Federal Institute, Iporá, Goiás, Brazil, CEP 76200-000.

${ }^{3}$ Corresponding author: sdonkin@purdue.edu glycerol feeding may indicate regulation of hepatic gene expression by changes in rumen propionate production. Key words: glycerol, gluconeogenesis, transition cow

\section{Short Communication}

Glycerol is a byproduct of biodiesel production, which is increasing with the current emphasis on alternatives to petroleum, thus reducing some of the historical cost constraints for glycerol as a feed ingredient. Previous research has supported use of oral administration of glycerol to alleviate ketosis (Johnson, 1954; Goff and Horst, 2003) and as an energy substrate and glucose precursor that increases feed intake and improves energy balance (Fisher et al., 1971, 1973). Previous feeding studies have indicated that glycerol can be incorporated into rations of mid-lactation cows to $15 \%$ of ration DM (Chung et al., 2007; Donkin et al., 2009) without adverse effects on cow health, milk production, or milk composition. Incorporation of glycerol to $11.5 \%$ of DM in rations for transition cows also did not negatively affect feed intake or milk production (Carvalho et al., 2011). Feeding glycerol reduced feed sorting in transition cows and increased the proportion of propionate and butyrate in the rumen, at the expense of acetate (Carvalho et al., 2011).

Propionate produced in the rumen is the primary gluconeogenic precursor in ruminant animals (Wiltrout and Satter, 1972; Lomax and Baird, 1983; Annison and Bryden, 1999) and conversion of propionate carbon to glucose is controlled by the abundance of cytosolic phosphoenolpyruvate (PEPCK-C), a key enzyme for gluconeogenesis in liver (Aschenbach et al., 2010). Increased expression of PEPCK-C in transition cows is linked to increased ruminal propionate production, including increased feed intake (Greenfield et al., 2000) and monensin feeding (Karcher et al., 2007) and suggests feed-forward control of propionate metabolism. Given the shift in VFA produced in the rumen with dietary glycerol inclusion (Carvalho et al., 2011), we hypothesized that inclusion of glycerol into transition cow diets would alter gluconeogenic enzymes, specifi- 
Table 1. Ingredient and nutrient composition of the pre- and postpartum experimental diets

\begin{tabular}{|c|c|c|c|c|}
\hline \multirow[b]{2}{*}{ Item } & \multicolumn{2}{|c|}{ Prepartum } & \multicolumn{2}{|c|}{ Postpartum } \\
\hline & Control & Glycerol & Control & Glycerol \\
\hline \multicolumn{5}{|l|}{ Ingredient, $\%$ of DM } \\
\hline Corn silage & 35.4 & 35.4 & 39.0 & 39.0 \\
\hline Alfalfa haylage & 8.0 & 8.0 & 15.5 & 15.5 \\
\hline Grass hay & 13.0 & 13.0 & 3.5 & 3.5 \\
\hline Wheat straw & - & - & 1.5 & 1.5 \\
\hline Cotton seed hulls & 6.0 & 6.0 & - & - \\
\hline Soybean hulls & 7.8 & 7.8 & 2.0 & 2.0 \\
\hline High moisture corn & 14.0 & - & 12.5 & - \\
\hline Glycerol & - & 11.5 & - & 10.8 \\
\hline Soybean meal & - & 2.5 & 10.0 & 11.0 \\
\hline Megalac $\mathrm{R}^{1}$ & - & - & 0.7 & 0.7 \\
\hline Protein blend ${ }^{2}$ & - & - & 5.3 & 6.0 \\
\hline Supplement ${ }^{3,4}$ & 15.8 & 15.8 & 10.0 & 10.0 \\
\hline \multicolumn{5}{|l|}{ Chemical composition ${ }^{5}$} \\
\hline $\mathrm{DM}, \%$ & 50.9 & 49.4 & 46.8 & 46.0 \\
\hline $\mathrm{CP}, \%$ of $\mathrm{DM}$ & $16.6(1.00)$ & $16.6(1.35)$ & $18.2(0.83)$ & $18.7(1.00)$ \\
\hline $\mathrm{ADF}, \%$ of $\mathrm{DM}$ & $22.9(1.75)$ & $25.5(1.79)$ & $19.5(1.77)$ & $20.8(2.32)$ \\
\hline $\mathrm{NDF}, \%$ of DM & $38.0(1.18)$ & $42.2(1.35)$ & $31.4(2.71)$ & $34.2(1.67)$ \\
\hline Starch, \% of DM & $22.6(2.64)$ & $15.0(1.22)$ & $26.7(1.73)$ & $19.2(1.12)$ \\
\hline $\mathrm{NE}_{\mathrm{L}}, \mathrm{Mcal} / \mathrm{kg}$ of DM & $1.58(0.02)$ & $1.61(0.05)$ & $1.65(0.02)$ & $1.61(0.02)$ \\
\hline $\mathrm{Ca}, \%$ of $\mathrm{DM}$ & $1.09(0.17)$ & $1.02(0.12)$ & $1.11(0.07)$ & $1.11(0.20)$ \\
\hline $\mathrm{P}, \%$ of $\mathrm{DM}$ & $0.36(0.02)$ & $0.34(0.02)$ & $0.43(0.02)$ & $0.40(0.04)$ \\
\hline $\mathrm{Mg}, \%$ of $\mathrm{DM}$ & $0.39(0.04)$ & $0.36(0.02)$ & $0.36(0.04)$ & $0.35(0.02)$ \\
\hline $\mathrm{K}, \%$ of DM & $1.22(0.05)$ & $1.29(0.09)$ & $1.47(0.11)$ & $1.44(0.03)$ \\
\hline $\mathrm{Na}, \%$ of $\mathrm{DM}$ & $0.15(0.01)$ & $0.15(0.01)$ & $0.32(0.01)$ & $0.32(0.02)$ \\
\hline
\end{tabular}

${ }^{1}$ Church \& Dwight Co., Princeton, NJ.

${ }^{2}$ Contained $44 \%$ Aminoplus (Ag Processing Inc., Omaha, NE), 3\% menhaden fish meal, 53\% ProvAAL STD 5000 (Perdue Agribusiness, Salisbury, MD).

${ }^{3}$ Prepartum: contained $38.29 \%$ soybean meal, $25.65 \%$ Bio-Chlor (Church \& Dwight Co.), $5.4 \% \mathrm{CaCO}_{3}, 2.16 \%$ dicalcium phosphate, $1.08 \% \mathrm{MgO}, 1.08 \% \mathrm{NaCl}, 1.65 \%$ mineral-vitamin premix $(16.11 \% \mathrm{Ca}, 2.11 \% \mathrm{~S}, 31,505$ $\mathrm{mg} / \mathrm{kg} \mathrm{Zn}, 8,036 \mathrm{mg} / \mathrm{kg} \mathrm{Cu}, 26,020 \mathrm{mg} / \mathrm{kg} \mathrm{Mn}, 140 \mathrm{mg} / \mathrm{kg} \mathrm{Se}, 473 \mathrm{mg} / \mathrm{kg} \mathrm{Co}, 284 \mathrm{mg} / \mathrm{kg} \mathrm{I}, 1,440 \mathrm{kIU} / \mathrm{kg}$ vitamin A, $416 \mathrm{kIU} / \mathrm{kg}$ vitamin D, 6,647 IU/kg vitamin E), 2.16\% $\mathrm{MgSO}_{4}, 5.08 \%$ Megalac R (Church \& Dwight Co.), $0.49 \%$ Niacinamide (99.5\% niacin), $2.62 \%$ yeast culture (Diamond V Mills, Cedar Rapids, IA), $1.8 \%$ vitamin E 20,000, 0.08\% Rumensin 80 (Elanco, Greenfield, IN), 2.62\% Omnigen-AF (Prince-Agri Products, Quincy, IL), $1.08 \%$ urea, $4.38 \%$ blood meal, $3.81 \%$ Aminoplus, $0.57 \%$ menhaden fish meal.

${ }^{4}$ Postpartum: contained $25 \%$ dried molasses, $42.75 \%$ finely ground corn, $7.5 \% \mathrm{CaCO}_{3}, 5 \%$ dicalcium phosphate, $6.2 \% \mathrm{NaHCO}_{3}, 2 \% \mathrm{MgO}, 2 \%$ DCAD plus, $0.5 \%$ potassium magnesium sulfate, $2.5 \% \mathrm{NaCl}, 2.025 \%$ mineral/ vitamin premix $(16.11 \% \mathrm{Ca}, 2.11 \% \mathrm{~S}, 31,505 \mathrm{mg} / \mathrm{kg} \mathrm{Zn}, 8,036 \mathrm{mg} / \mathrm{kg} \mathrm{Cu}, 26,020 \mathrm{mg} / \mathrm{kg} \mathrm{Mn}, 140 \mathrm{mg} / \mathrm{kg} \mathrm{Se}$, $473 \mathrm{mg} / \mathrm{kg} \mathrm{Co}, 284 \mathrm{mg} / \mathrm{kg} \mathrm{I}, 1,440 \mathrm{kIU} / \mathrm{kg}$ vitamin A, $416 \mathrm{kIU} / \mathrm{kg}$ vitamin D, 6,647 IU $/ \mathrm{kg}$ vitamin E), $0.25 \%$ Niacinamide (99.5\% niacin), 2\% yeast culture (Diamond V Mills), 0.213\% vitamin E 20,000, 0.062\% Rumensin 80, 2\% Omnigen-AF (Prince-Agri Products).

${ }^{5}$ Mean (SD) analysis for composite samples $(\mathrm{n}=5)$.

cally PEPCK-C. The objective of this experiment was to determine the effects of replacing high-moisture corn with glycerol on expression of hepatic gluconeogenic enzymes during the transition to lactation period.

Twenty-six multiparous Holstein cows were paired by expected calving date and randomly assigned to receive either a diet containing corn silage, alfalfa haylage, hay, high-moisture corn, cottonseed hulls, soybean hulls, vitamins, and minerals (control) or a diet in which high-moisture ear corn was replaced with a mixture of glycerol and soybean meal (glycerol). Refined glycerol (99.5\% USP grade glycerin; Pt Sumi Ashi Oleochemicals Industry, Jakarta, Indonesia) was included at 11.5 and $10.8 \%$ of the ration DM for the pre- and postpartum diets, respectively (Table 1). Soybean meal was added to the glycerol diets to adjust for the protein removed from the diet with the removal of high-moisture corn.

Cows were housed in individual tie stalls at the Purdue Dairy Research and Education Center (W. Lafayette, IN) and fed diets formulated to meet or exceed the NRC (2001) guidelines for 600-kg dairy cattle. Diets were fed as a TMR once daily between 0630 to 0730 $\mathrm{h}$ in amounts that ensured ad libitum consumption and approximately 10 to $15 \%$ feed refusals. Cows were milked twice daily at approximately 0700 and $1830 \mathrm{~h}$. Animal use and handling protocols were approved by the Purdue Animal Care and Use Committee.

Liver biopsy samples were collected on $-28,-14$, $+1,+14,+28$, and +56 d relative to calving (DRTC), as described previously (Greenfield et al., 2000; Velez 
and Donkin, 2005; White et al., 2011). Liver tissue samples were immediately rinsed in saline, snap frozen, and stored at $-80^{\circ} \mathrm{C}$ for subsequent hepatic transcript quantification. Only cows with a complete set of liver biopsy samples were used for gene expression analysis (control, $\mathrm{n}=11$; glycerol, $\mathrm{n}=12$ ).

Total RNA was isolated using Trizol reagent (Invitrogen, Carlsbad, CA), quantified, cleaned, and used to generate cDNA for quantitative $\mathrm{PCR}$, as done previously (White et al., 2011, 2012). Abundance of mRNA transcripts was quantified using real-time PCR, brilliant SYBR Green reagent, and QPCR Master Mix (Stratagene, Cedar Creek, TX), controls, and cycling conditions described previously (White et al., 2011, 2012). The abundance of pyruvate carboxylase (PC; EC 6.4.1.1), PEPCK-C (EC 4.1.1.32), mitochondrial PEPCK (PEPCK-M; EC 4.1.1.32), glucose-6-phosphatase (G6Pase; EC 3.1.3.9), and 18S (gene number 493779) mRNA were determined using quantitative real-time PCR. Primers were as follows: PC, CCACGAGTTCTCCAACACCT (forward), TTCTCCTCCAGCTCCTCGTA (reverse); PEPCK-C, AACCTGGCCATGATGAACCCTACT (forward), ACTCCTTGCCCTTCCAGGAAATGA (reverse); PEPCK-M, TGACTGGGCAAGG GGAGCCG (forward), GGGGCCACCCCAAAGAAGCC (reverse); G6Pase, TGATGGACCA AGAAAGATCCAGGG (forward), TAGGGATTGACCTCACTGGCCCTCTT (reverse); and 18S, ACCCATTCGAACGTCTGCCCTATT (forward), TCCTTGGATTGTGGTAGCCGTT TCT (reverse). All samples, standards, and controls were analyzed in triplicate and mean values normalized to 18S mRNA abundance within each sample. Reaction efficiencies were between 90 and $110 \%$ based on standard curve sample analysis. Calculated PCR amplification efficiencies (Eff $=10^{-1 / \text { slope }}$; Ramakers et al., 2003) were as follows: PC 1.91, PEPCK-C 1.94, PEPCK-M 1.96, G6Pase 1.99, and $18 \mathrm{~S} 1.96$. The use of $18 \mathrm{~S}$ for data normalization was verified by the lack of an effect of treatment or DRTC on the threshold cycle or quantity, and differences in threshold cycle values of $<1$ between treatment groups, indicating a lack of bias by the housekeeping gene. Although methods of normalization and selection of reference genes vary, $18 \mathrm{~S}$ is consistently expressed in hepatic tissue during periods of physiological regulation, lipid accumulation, and toxicity in the liver (Boujedidi et al., 2012; Lardizábal et al., 2012; Matoušková et al., 2014).

Data were analyzed used the MIXED procedure of SAS 9.2 (SAS Inst. Inc., Cary, NC). Data were interrogated for normality of error variance and met all the assumptions of normal, independent, and random distribution. Data for relative abundance of mRNA were based on analysis using a reference standard curve, and resulting values were analyzed for repeated measures using a model that accounted for the fixed effect of time and the random effect of cow within treatment. Means were considered different when $P<0.05$ and tended to differ if $0.05 \leq P \leq 0.10$. Tukey-Kramer studentized adjustments were used to separate treatment means. Values reported are least squares means with associated standard errors.

Results for feed intake, milk production, milk composition, plasma metabolites, and rumen parameters have been reported previously (Carvalho et al., 2011). Relevant results will be presented briefly here. Prepartum and postpartum feed intake was not altered $(P \geq$ $0.05)$ by glycerol feeding (14.9 vs. $14.6 \pm 0.44$ and 19.8 vs. $20.7 \pm 0.51 \mathrm{~kg} / \mathrm{d}$ DMI, control vs. glycerol). Overall milk yield did not differ $(P \geq 0.05)$ with glycerol feeding (35.8 vs. $37.0 \pm 1.45 \mathrm{~kg} / \mathrm{d}$, control vs. glycerol), although cows fed glycerol tended to have greater milk production $(P<0.15)$ during the last 2 wk of the trial (wk 7 and 8 postcalving). Glycerol feeding did not alter $(P \geq 0.05)$ milk composition, BW change, or BCS change. Blood glucose concentration was decreased $(P$ $<0.05)$ in cows fed glycerol during the prepartum period $(59.1$ vs. $53.4 \pm 1.61 \mathrm{mg} / \mathrm{dL})$ and tended $(P=0.10)$ to be decreased in the postpartum period (53.6 vs. 50.8 $\pm 1.15 \mathrm{mg} / \mathrm{dL})$. Concentration of BHB was increased $(P<0.05)$ in cows fed glycerol during the prepartum period $(0.58$ vs. $0.82 \pm 0.04 \mathrm{mmol} / \mathrm{L})$ and tended $(P$ $=0.09)$ to be increased during the postpartum period (0.77 vs. $0.94 \pm 0.07)$. Serum NEFA concentration did not differ $(P \geq 0.05)$ between cows fed glycerol or control diets pre- and postpartum; however, overall, NEFA tended $(P=0.07)$ to be lower in cows fed glycerol $(0.35$ vs. $0.29 \pm 0.02 \mathrm{mmol} / \mathrm{L})$. Feeding glycerol did not alter $(P \geq 0.05)$ rumen $\mathrm{pH}$, glycerol, or total VFA concentration. Cows fed glycerol had increased $(P<0.05)$ propionate (22.7 vs. $28.6 \pm 1.44$ ), butyrate (11.5 vs. $15.3 \pm$ $0.71)$, and valerate (1.48 vs. $2.06 \pm 0.06)$ and decreased $(P<0.05)$ acetate $(61.4$ vs. $51.5 \pm 1.08)$, isobutyrate (1.11 vs. $0.92 \pm 0.05)$, and isovalerate (1.84 vs. $1.64 \pm$ 0.07 ), as a percent of total VFA. Overall, glycerol was a suitable replacement for high-moisture corn within diets of transition cows and did not negatively affect milk production (Carvalho et al., 2011).

Within hepatic tissue samples, expression of PC mRNA was increased $(P<0.05) 6$-fold at +1 DRTC and 4-fold +14 DRTC compared with precalving expression levels (Figure 1). Expression of PEPCK-C was increased $(P<0.05) 2.5$ - and 3 -fold at +14 and +28 DRTC compared with that at +1 DRTC. The ratio of PC to PEPCK-C was increased $(P<0.05) 6.3$-fold at +1 DRTC compared with precalving. Expression of PEPCK-M and G6Pase were not altered $(P \geq 0.05)$ by DRTC. These data are consistent with previous reports 
A.

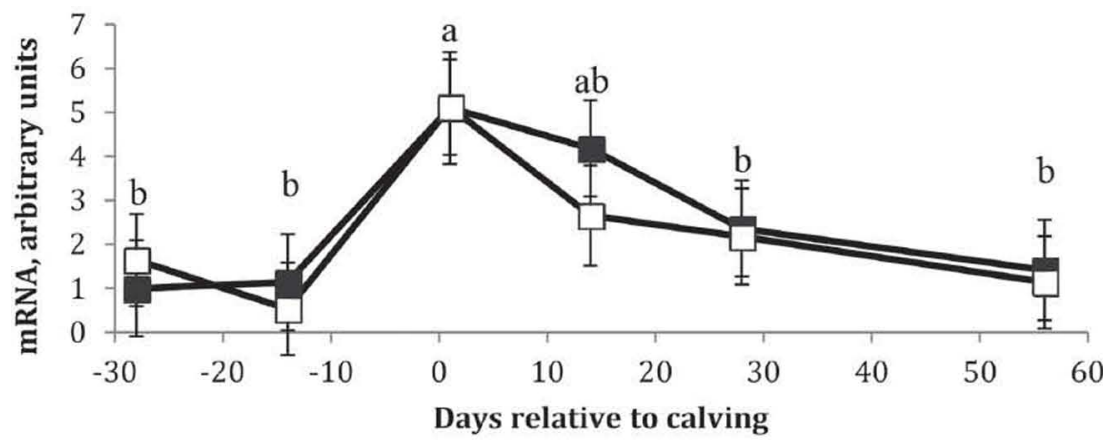

B.

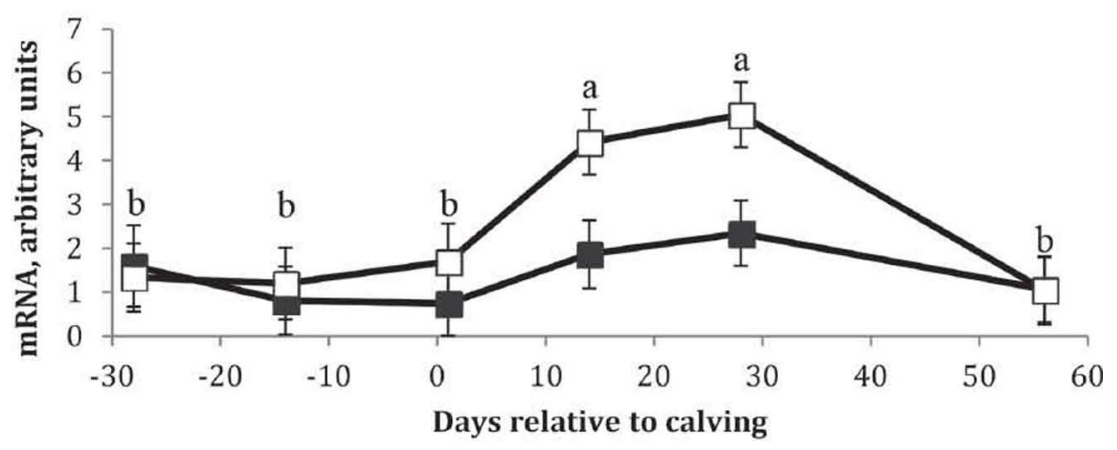

C.

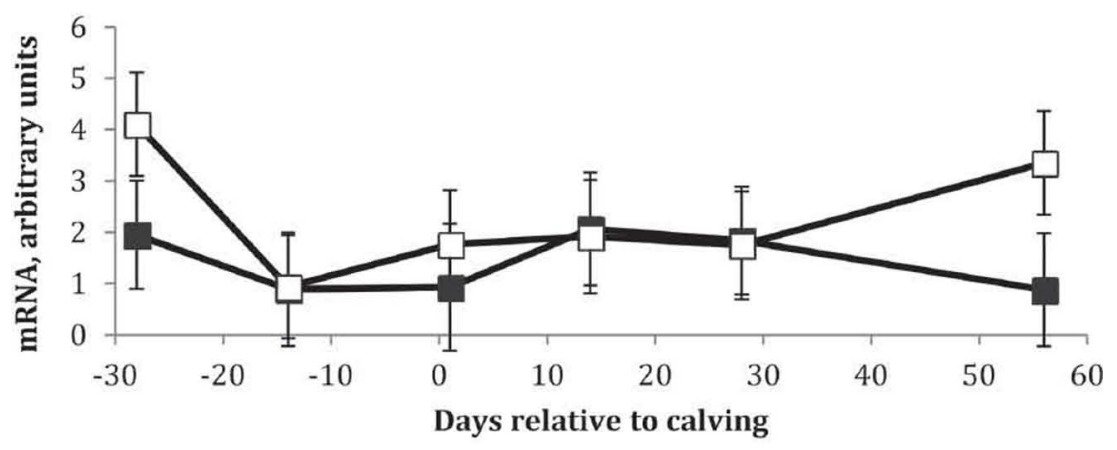

D.

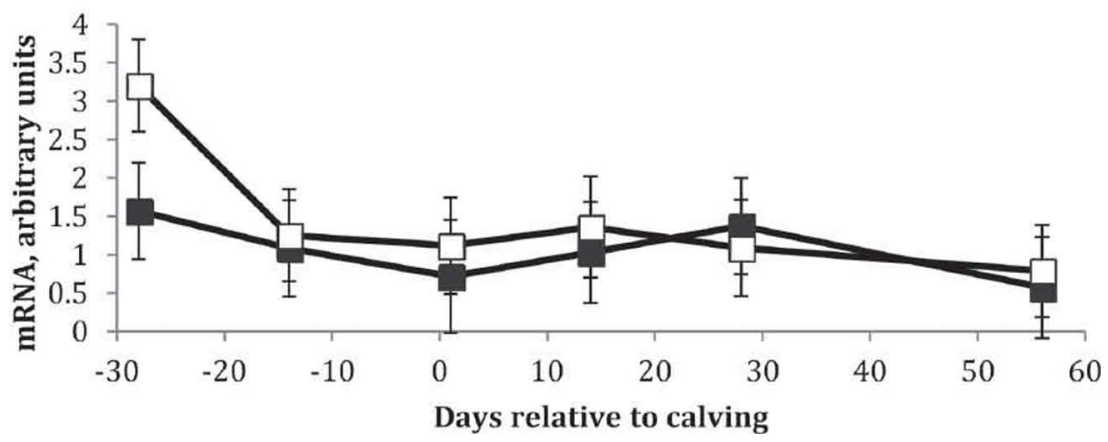

Figure 1. Expression of (A) pyruvate carboxylase, (B) cytosolic phosphoenolpyruvate carboxykinase, (C) mitochondrial phosphoenolpyruvate carboxykinase, and (D) glucose-6-phosphatase mRNA in liver samples from cows fed glycerol $(\square ; \mathrm{n}=12)$ or control $(\mathbf{\square}$; $\mathrm{n}=11)$ diet and across the transition to lactation period. Data are relative quantity of gene expression (arbitrary units) based on standard curve analysis. Letters $(\mathrm{a}, \mathrm{b})$ that differ within panel denote differences $(P<0.05)$ of day relative to calving. Feeding glycerol increased $(P<0.05)$ cytosolic phosphoenolpyruvate carboxykinase mRNA expression but did not alter $(P \geq 0.05)$ expression of other transcripts. There was no interaction of diet and day relative to calving for any transcript. 
of the effect of feed restriction and the transition to lactation on gluconeogenic enzymes (Greenfield et al., 2000; Velez and Donkin, 2005; White et al., 2011, 2012).

Pyruvate carboxylase uniquely affects many anaplerotic and cataplerotic processes that require oxaloacetate (OAA), including gluconeogenesis, tricarboxylic acid cycle activity, insulin secretion, and fatty acid metabolism (Jitrapakdee et al., 1999, 2006). Equally important in metabolism is the potential drain from the OAA pool through the action of PEPCK to commit carbons to gluconeogenesis. Therefore, the balance of PC and PEPCK activities may be critical in determining the metabolic competency of liver for the transition dairy cow. Insufficient PC relative to PEPCK in the liver could act to deplete the OAA pool and compromise the capacity of the tricarboxylic acid cycle to oxidize acetyl CoA from $\beta$-oxidation of NEFA. The increase in $\mathrm{PC}$, but not PEPCK, observed here and in our previous studies (Greenfield et al., 2000), may safeguard against OAA depletion at calving and instead serve to shift liver metabolism to favor greater capacity for gluconeogenesis from lactate. The increase in PEPCK with glycerol feeding may be a consequence of an increase in propionate supply, assuming that the increase in rumen VFA with glycerol feeding (Carvalho et al., 2011) translates to increased supply to liver. This response for PEPCK is consistent with the effects of Rumensin to induce PEPCK in transition cows (Karcher et al., 2007). Therefore, it appears that feeding conditions that are consistent with increased propionate supply in dairy cattle serve to induce hepatic PEPCK. The coordination of increased PEPCK with a greater supply of propionate may provide a protective effect against depletion of the OAA pool and favor metabolic competency of transition cows. The mechanism responsible for this induction has not been fully described for bovine but available data suggest a direct effect of propionate to regulate activity of the PEPCK gene promoter (Zhang et al., 2014).

We detected no effects $(P \geq 0.05)$ of glycerol feeding on mRNA expression of PC, PEPCK-M, or G6Pase. Overall, expression of PEPCK-C mRNA was greater $(P<0.05)$ in cows fed glycerol $(1.40$ vs. $2.45 \pm 0.32$ arbitrary units, control vs. glycerol). The ratio of $\mathrm{PC}$ to PEPCK-C tended $(P=0.10)$ to be decreased in cows fed glycerol (3.23 vs. $1.71 \pm 0.65$, control vs. glycerol). There were no interactions $(P \geq 0.05)$ of diet and DRTC for mRNA expression of any transcripts quantified. The increase of PEPCK-C expression is likely related to the increased rumen production of propionate in cows fed glycerol. Propionate appears to regulate bovine hepatic PEPCK-C through control of specific elements within the PEPCK-C gene promoter (Zhang et al., 2014). The effect of glycerol on PEPCK-C, and not PEPCK-M, expression highlights the role of the cytosolic enzyme to regulate use of propionate for glucose production. Increased PEPCK-C expression without an increase in PC expression during glycerol feeding could have increased gluconeogenesis from propionate, resulting in greater hepatic glucose production. Although this potential increase in gluconeogenesis is not observed as an increase in blood glucose concentration, it is highly likely that any additional glucose produced by the liver would be taken up by peripheral tissues, including mammary, and thus, no net change in blood glucose concentration observed. This regulation of hepatic gluconeogenic enzymes could have contributed to the tendency for increased milk production during the final 2 wk of the trial. Concomitantly, the decreased ratio of PC to PEPCK-C may have decreased the capacity of the tricarboxylic acid cycle for complete oxidation of acetyl CoA from NEFA oxidation. This could have contributed to the increased BHB concentration in cows fed glycerol, which was observed but not explainable by production data alone.

In conclusion, replacing high-moisture corn with glycerol in transition cow diets increased PEPCK-C expression without changing expression of PC, PEPCK-M, or G6Pase. The increase in PEPCK-C expression may be linked to increased propionate supply from the rumen of cows fed glycerol and may contribute to an increase in capacity for gluconeogenesis from propionate.

\section{ACKNOWLEDGMENTS}

This project was supported by National Research Initiative Competitive Grant no. 2009-35900-05970 from the USDA Cooperative State Research, Education, and Extension Service (Washington, DC).

\section{REFERENCES}

Annison, E. F., and W. L. Bryden. 1999. Perspectives on ruminant nutrition and metabolism. II. Metabolism in ruminant tissues. Nutr. Res. Rev. 12:147-177.

Aschenbach, J. R., N. B. Kristensen, S. S. Donkin, H. M. Hammon, and G. B. Penner. 2010. Gluconeogenesis in dairy cows: The secret of making sweet milk from sour dough. IUBMB Life 62:869-877.

Boujedidi, H., L. Bouchet-Delbos, A.-M. Cassard-Doulcier, M. NjikéNakseu, S. Maitre, S. Prévot, I. Dagher, H. Agostini, C. S. Voican, D. Emilie, G. Perlemuter, and S. Naveau. 2012. Housekeeping gene variability in the liver of alcoholic patients. Alcohol. Clin. Exp. Res. 36:258-266.

Carvalho, E. R., N. S. Schmelz-Roberts, H. M. White, P. H. Doane, and S. S. Donkin. 2011. Replacing corn with glycerol in diets for transition dairy cows. J. Dairy Sci. 94:908-916.

Chung, Y. H., D. E. Rico, C. M. Martinez, T. W. Cassidy, V. Noirot, A. Ames, and G. A. Varga. 2007. Effects of feeding dry glycerin to early postpartum Holstein dairy cows on lactational performance and metabolic profiles. J. Dairy Sci. 90:5682-5691.

Donkin, S. S., S. L. Koser, H. M. White, P. H. Doane, and M. J. Cecava. 2009. Feeding value of glycerol as a replacement for corn grain in rations fed to lactating dairy cows. J. Dairy Sci. 92:5111-5119. 
Fisher, L. J., J. D. Erfle, G. A. Lodge, and F. D. Sauer. 1973. Effects of propylene glycol or glycerol supplementation of the diet of dairy cows on feed intake, milk yield and composition, and incidence of ketosis. Can. J. Anim. Sci. 53:289-296.

Fisher, L. J., J. D. Erfle, and F. D. Sauer. 1971. Preliminary evaluation of the addition of glucogenic materials to the rations of lactating cows. Can. J. Anim. Sci. 51:721-727.

Goff, J. P., and R. L. Horst. 2003. Oral glycerol as a gluconeogenic precursor in the treatment of ketosis and fatty liver. Acta Agric. Scand. 44(Suppl 1):40. (Abstr.)

Greenfield, R. B., M. J. Cecava, and S. S. Donkin. 2000. Changes in mRNA expression for gluconeogenic enzymes in liver of dairy cattle during the transition to lactation. J. Dairy Sci. 83:1228-1236.

Jitrapakdee, S., A. Vidal-Puig, and J. C. Wallace. 2006. Anaplerotic roles of pyruvate carboxylase in mammalian tissues. Cell. Mol. Life Sci. 63:843-854.

Jitrapakdee, S., M. E. Walker, and J. C. Wallace. 1999. Functional expression, purification, and characterization of recombinant human pyruvate carboxylase. Biochem. Biophys. Res. Commun. 266:512-517.

Johnson, R. B. 1954. The treatment of ketosis with glycerol and propylene glycol. Cornell Vet. 44:6-21.

Karcher, E. L., M. M. Pickett, G. A. Varga, and S. S. Donkin. 2007. Effect of dietary carbohydrate and monensin on expression of gluconeogenic enzymes in liver of transition dairy cows. J. Anim. Sci. 85:690-699.

Lardizábal, M. N., A. L. Nocito, S. M. Daniele, L. A. Ornella, J. F. Palatnik, and L. M. Veggi. 2012. Reference genes for real-time PCR quantification of microRNAs and messenger RNAs in rat models of hepatotoxicity. PLoS ONE 7:e36323.
Lomax, M. A., and G. D. Baird. 1983. Blood flow and nutrient exchange across the liver and gut of the dairy cow. Effects of lactation and fasting. Br. J. Nutr. 49:481-496.

Matoušková, P. H. Bártíková, I. Boušová, V. Hanušová, B. Szotáková, and L. Skálová. 2014. Reference genes for real-time PCR quantification of messenger RNAs and microRNAs in mouse model of obesity. PLoS ONE 9:e86033.

NRC. 2001. Nutrient Requirements of Dairy Cattle. 7th rev. ed. Natl. Acad. Sci., Washington, DC.

Ramakers, C., J. M. Ruijter, R. H. Lekanne Deprez, and A. F. M. Moorman. 2003. Assumption-free analysis of quantitative real-time polymerase chain reaction (PCR) data. Neurosci. Lett. 339:62-66.

Velez, J. C., and S. S. Donkin. 2005. Feed restriction induces pyruvate carboxylase but not phosphoenolpyruvate carboxykinase in dairy cows. J. Dairy Sci. 88:2938-2948.

White, H. M., S. S. Donkin, M. C. Lucy, T. M. Grala, and J. R. Roche. 2012. Short communication: Genetic differences between New Zealand and North American dairy cows alter milk production and gluconeogenic enzyme expression. J. Dairy Sci. 95:455-459.

White, H. M., S. L. Koser, and S. S. Donkin. 2011. Bovine pyruvate carboxylase $5^{\prime}$ untranslated region variant expression during transition to lactation and feed restriction in dairy cows. J. Anim. Sci. 89:1881-1892.

Wiltrout, D. W., and L. D. Satter. 1972. Contribution of propionate to glucose synthesis in the lactating and nonlactating cow. J. Dairy Sci. 55:307-317.

Zhang, Q., S. L. Koser, and S. S. Donkin. 2014. Propionate is a dominant inducer of bovine cytosolic phosphoenolpyruvate carboxykinase (PCK1) expression. FASEB J. 28(1 Suppl.):818.11. (Abstr.) 